\title{
Thinking about Translation
}

H ere's a big caveat to begin with-my real translating excitement doesn't come in translating narrative or explanatory prose. The thing Monsieur Jourdain wasn't doing and that, I venture to think, none of us ever feels we do well enough - that is, the trying to render a poetic text, albeit a poetic prose text, into something that we can, perhaps others can, live with.

So it's like this: I can't imagine anything more exciting than the moment I sit down to start a new translation, or then the moments that follow that one. Let me point out, though, that, unlike my beloved frequent cotranslator Patricia Terry, who can miraculously render poems into rhymed and rhythmic equivalents of themselves, I don't do the rhyme thing. What I want to do and mean to do has the wish to bring over the something or other inside the poem into the sort of English that makes interior sense.

New things all the time in translation. Recently, I heard Clive Scott, Mr. Poetics in the UK, as we think of him, speak on the livingness of translations, on the Bergsonian view of the motion they must keep in their intention and being, and on his recent conversion away from the linear to the tabular typographic. This shift in the translational mind set he described as related to metatypography of the Meschonnic sort, with a "renewed self-consciousness" at every deviation of font, like differing architectures or "sculpturing mechanisms." "A tabular text," he points out, "cannot be quoted -it can only perform itself or be performed-or shifted to a support with a different format." It's always in draft form. But in its invitation to infinite reconstructions, redispositions, and potentialities, he claims that it makes available choice and chance. His excitement about it was palpable, demonstrable, and incredibly complicated for listeners like me. That isn't where I'm going, but the livingness of it got right across. The point of all our continuing stress on translational possibilities is just that: the excitement of the thing. 
Now the translational field that I most work in is that of art and text: the translation of former art into present art, and of the written or spoken language into the visual one. That said, though, I had more actual fun writing the very diverse chapters of a book of just plain literary translation, Surprised in Translation, than I could possibly have imagined. To look at the ways Roger Fry and others, Bloomsburyians and not, deal with Mallarmé, or Mallarmé dealt with Whistler's “Ten O'Clock," or the ways Beckett deals with Beckett, or the way Pound chops up Rimbaud and makes the new half-size poems work, or Bonnefoy stretches out Yeats and the sonnets of Shakespeare is right up there with the delights of being. And I got to express my anger about the slaughter of Virginia Woolf in French, what could be more relieving to an impassioned reader betrayed? But of course the real joy was finally saying something about what it was like to work for so long with such commitment to the poems of René Char, to work by his side and near his lavender field. I've no idea if that part comes across with anything like the radiance I bathed in so many years, but I can only hope so.

The thing I like the most about making new translations is the reading aloud of both texts, the original and the one you just gave birth to, so you can change the language and the perception of the document. Something about shaping it afresh gives you a fresh delight every time. What gives you hope as a translator is often the new openings there seem to be. There are, everywhere springing up, all sorts of new ventures, such as, on the poetry translation front, the new venture of Black Widow Press, which is soaring through a series of French-language poets-Tzara, Eluard, Breton, Guillevic, Desnos, Laforgue, soon to be Char, Reverdy, and others. New openings now.

Those are the two clues I would take to my present optimism about the work of translation. First, openness, which seems to me to be present in much that has to do with poetry and indeed with translation. It is about revivifying works old, medium-old, and new, things we had forgotten about, taken for granted or left aside.

And the final clue is the nowness of it, like the recent notice taken, in the New York Times, of small poetry magazines, such as Circumference, for which I just translated last week Bernard Noel's latest poem, called "Le Jardin d'encre"- that garden of ink is the one all of us as translators inhabit for a good part of our lives.

This poem seemed to me straightaway to be consoling in its presentness and - to develop a notion from the first line-a kind of "despiteness": 
et maintenant c'est encore maintenant bien que tout glisse and now it's still now despite everything sliding

Everything slides, yes, but arrives somewhere positive, at the final limit, at the concluding lines of this long poem:

et maintenant allons main dans la main au jardin d'encre l'arbre qu'a planté le pinceau est aussi un arbre de mémoire et renaissante la lecture est là qui bruit parmi les feuilles

and now we go hand in hand to the garden of ink the tree that the brush planted is also of memory and the reading reborn rustles there among the leaves

From my point of view, chief among the important things about this poem is that from the initial sliding down to the final tree of memory and the reading among the leaves in this garden of ink so entitled in both senses, all the expressions work in the present. The final optimistic merging of text and nature, of rebirth inside and out, of what is thought and written and what is experienced collectively and greenly, seems to me to awaken that great surrealist saying: "Always for the first time." This garden matters greatly to all of us here and to all of us, who care about translation and poetry.

(C) Mary Ann Caws 